This document is the Submitted Manuscript version of a Published Work that appeared in final form in:

Román M.V., Arto I., Ansuategi A. 2019. International trade and the distribution of economy-wide benefits from the disbursement of climate finance. Climate and Development. 11. (8) 639-654. DOI (10.1080/17565529.2018.1521330). (C) 2018 Informa UK Limited, trading as Taylor \& Francis Group.

This manuscript version is made available under the CC-BY-NC-ND 3.0 license http://creativecommons.org/licenses/bync-nd/3.0/ 


\title{
International trade and the distribution of economy-wide benefits from the disbursement of climate finance
}

\begin{abstract}
In the framework of recent international climate negotiations, industrialised countries have committed to transfer at least USD 100 billion per year to developing countries from 2020. Climate finance has become the subject of an already extensive literature. However, the economic impact of the disbursement of climate finance and the role of international trade in its distribution globally have not been studied yet. This paper specifically estimates the geographical distribution of economic benefits for 17 mitigation and 9 adaptation options. We use a Global Multi-Regional Input-Output framework to track both domestic as well as spill-over effects of climate finance disbursements. The relevance of spill-overs is confirmed: on average, 29\% of the economic benefits of climate actions flow to countries different from the recipient country (i.e. to the donors and third countries). But this percentage varies widely, between 11 and $61 \%$ depending on the type of climate action implemented as well as the recipient country. The findings are expected to be of interest for both recipient and donor countries as they provide guidance on how to maximize the economic co-benefits of climate finance.
\end{abstract}

Keywords: climate finance, international trade, GMRIO, development

\section{Introduction}

Financial resources are needed for both climate change mitigation and adaptation. Large-scale investments are required to significantly reduce emissions, notably in sectors that emit large quantities of greenhouse gases (GHGs). The International Energy Agency estimates that achieving a low-carbon energy sector will require an average of United States dollar (USD) 1.2 trillion in additional investments annually up to 2050 (IEA, 2014). On the other hand, according to the Adaptation Gap Report (UNEP, 2014), the global cost of adaptation is currently estimated to range between USD 70 billion and more than 100 billion per year by 2050. However, the dispersion and heterogeneity of adaptation measures make cost estimates very uncertain and probably biased downwards. 
Most developing countries face financial constraints (public as well as private), and significant additional costs imposed on their development by the impacts of climate change. Therefore, bilateral/multilateral public and private financing are all likely to be important sources of funding for their mitigation and adaptation activities. Climate finance is a critical topic in the United Nations' climate talks and industrialised countries have committed to provide assistance to developing countries at the Copenhagen Accord, and in the Cancun and Paris Agreements of the United Nations Framework Convention on Climate Change (UNFCCC, 2009, 2010, 2015). In these international agreements the higher-income countries have jointly pledged up to USD 30 billion in Fast Start Finance (FSF) for lower-income countries in the period 20102012 and, in terms of long-term finance, USD 100 billion annually from 2020 onwards (and a larger amount, still to be determined, after 2025).

Some governments have started to mobilize financial resources to support developing countries' mitigation and adaptation actions. The commitment for the FSF period was reached, especially due to the contributions by Germany, Japan, Norway, the United Kingdom (UK) and the United States of America (USA) (Gupta et al., 2014). However, developed countries are far from reaching the long-term finance goal of USD 100 billion per year. According to OECD/CPI estimates, developed countries were able to mobilize and transfer USD 57 billion on average in 2013-2014 (OECD \& CPI, 2015). This estimate does not include the initial capitalisation of the Green Climate Fund (GCF), which accounts for USD 10.3 billion as of December 2016 (GCF, 2016). In September 2016, the five main contributors to climate funds (including the GCF) were UK (USD 11,228 million), Norway (USD 6,606 million), USA (USD 5,750 million), Germany (USD 4,203 million), and Japan (USD 3,208 million) ${ }^{1}$. Experts agree that climate finance must be accelerated and scaled up to put the world on track to attain climate-neutral and resilient development in this century (Gupta et al., 2014).

So far, mitigation projects have accumulated the largest share of climate finance flowing from developed to developing countries. This bias towards mitigation was already detected in the FSF period, when mitigation was receiving $72 \%$ of contributions (Nakhooda, Fransen, Kuramochi, \& Caravani, 2013). According to the OECD estimates of the 2013-2014 flows, the thematic distribution of these transfers has been $77 \%$ to mitigation, $16 \%$ to adaptation and $7 \%$ to cross-cutting actions (OECD \& CPI, 2015). Buchner, Trabacchi, Mazza, Abramskiehn, \& Wang (2015), accounting not 
only for internationally provided funding but also for domestically mobilized resources, found a strong bias towards mitigation in 2014, particularly towards renewable energy. Adaptation projects seem to have more difficulties in attracting funding than mitigation projects. Exceptions are East Asia (EA) and the Pacific and Sub-Saharan Africa where $56 \%$ of total climate finance is for adaptation, especially for measures in the water- and wastewater sector (ibid).

A rapidly growing body of literature on climate finance is emerging, including the study of the drivers of international transfers. Authors addressing this question from a theoretical perspective have identified different causes for the current bias towards the financing of mitigation over adaptation. These causes include the "global public good" nature of mitigation in contrast to the local scope of adaptation, the cheap mitigation opportunities in developing countries, the existence of established business models and carbon markets, and the possibility to reduce future adaptation needs with investments in mitigation (Abadie, Galarraga, \& Rübbelke, 2013; Pickering \& Rübbelke, 2014; Pittel \& Rübbelke, 2013; Rübbelke, 2011). Empirical analysis highlights the relevance of country-specific factors, like their institutional, economic and political characteristics (Halimanjaya, 2015; Pickering et al., 2015).

This paper contributes to this body of literature by studying an aspect of climate finance that, to the best of our knowledge, has not been considered yet: the economic effects of expenditures driven by climate actions, taking into account the role of international trade. It is obvious that mitigation and adaptation actions linked to climate finance have economic impacts in terms of avoided costs of climate change. In addition, in some cases, these actions can have co-benefits in terms, for example, of health improvements due to the reduction of air pollution. However, these are not the only economic implications of climate finance. Like any other type of expenditure, projects and programmes aimed at reducing emissions and/or enhancing climateresilience require the production of goods and services, and hence, the creation of valueadded in various economic sectors at different locations. This paper quantifies the extent to which the benefits of climate action, in terms of value-added creation, are retained by recipient countries of climate finance or, by contrast, are captured by companies from other countries via international trade. Moreover, by assessing the economic effects of different types of climate actions in different locations, this paper provides information for climate finance allocation decisions. Note that the scope of the assessment of 
economic effects is limited to the phase of disbursement of climate finance. Another branch of the climate finance literature deals with the economic consequences of the mobilization of financial resources in donor countries (Basu, Finneran, Bishop, \& Sundararaman, 2011; IMF, 2011; Jones, Keen, \& Strand, 2013; Parker et al., 2010). We also keep out of the analysis the study of the effectiveness of climate finance in terms of avoided costs of future climate change.

The specific objectives of this paper can be summarized in three questions. First, how are the economic impacts of climate actions distributed between countries? Second, distinguishing for different types of mitigation and adaptation actions, how much of the impact spills over to non-recipient countries? And third, distinguishing for different disbursement options (i.e. combinations of recipient country and climate action), how much impact is captured by each donor country?

The article is divided into five sections. After this introduction (Section 1), the methods and materials are introduced in Section 2. Results are presented in Section 3, and discussed in Section 4. Section 5 presents conclusions and policy implications.

\section{Methods and materials}

\subsection{The Input-Output Model}

The Input-Output (IO) approach has been widely applied to various areas over the last 50 years (Han, Yoo, \& Kwak, 2004; Miller \& Blair, 2009). This is the most widely utilized approach for the analysis of macro-economic effects of major new expenditures, as is the case for investments driven by climate policies (e.g. Allan et al., 2008; Caldés, Varela, Santamaría, \& Sáez, 2009; Hienuki, Kudoh, \& Hondo, 2015; Markaki, BelegriRoboli, Michaelides, Mirasgedis, \& Lalas, 2013; Neuwahl, Löschel, Mongelli, \& Delgado, 2008; Oliveira, Coelho, da Silva, \& Antunes, 2013; Scott, Roop, Schultz, Anderson, \& Cort, 2008; Tourkolias \& Mirasgedis, 2011).

An IO table provides a picture of the market transactions taking place between the different actors (producers, households, government, etc.) of one economic system in a specific year. National IO tables, representing the national economic system, are appropriate for the assessment of domestic effects of new investments, but do not capture the impact in other countries (Herreras Martínez et al., 2013; Ziegelmann, 
Mohr, \& Unger, 2000). These effects, also called spill-over effects, refer to economic impacts outside of the economy where the expenditure is made, and are driven by international trade.

Given the growth of vertical specialization and the increasingly global nature of current supply chains (Francois, Manchin, \& Tomberger, 2015; Johnson \& Noguera, 2012; Koopman, Wang, \& Wei, 2012, 2014; Los, Timmer, \& de Vries, 2015; Nagengast \& Stehrer, 2016) ${ }^{2}$, Global Multiregional Input-Output (GMRIO) tables are a highly suitable tool for studies with a global scope, since they inherently reflect the current interconnectivity of the world's economies. They comprise information on global supply chains, reflecting the participation of the different sectors and countries in the production process of each single good or service. The information about interlinkages between industries makes it possible to comprehensively track the effect of an exogenous increase in demand throughout the global productive system. GMRIO tables allow us to trace the value-added created by all the labour and capital directly or indirectly needed for the production of final goods along their global value chains. This feature makes this framework suitable for the purpose of this paper (M. P. Timmer, Erumban, Los, Stehrer, \& de Vries, 2014). Spill-over effects of climate policy have been previously assessed using this framework at the European Union (EU) level (Arto, Amores, \& Rueda-Cantuche, 2015; Markandya, Arto, González-Eguino, \& Román, 2016). In the Appendix we show the formal structure of the multiregional IO model and how we have used it to analyze the effects of climate finance.

The IO method is based on the assumption of a linear relationship between inputs and production. It is also assumed that each sector produces one product, and that each sector has a single and constant input structure. The model ignores the possibility of substitution between inputs or the possibility of increasing/decreasing returns to scale and technical change. A change in output is supposed to produce a proportional change in inputs without affecting prices. These assumptions are only reasonable in the medium term (since the change in the economic structure can be assumed to occur relatively slowly), and in economies with excess capacity and involuntary unemployment, or for the study of relatively small interventions that will not affect prices (Ciorba, Pauli, \& Menna, 2004; Tourkolias \& Mirasgedis, 2011). These requisites are met in our case, since the focus is on short-term effects of expenditures that, due to their limited volume, cannot be expected to put pressure on wages and prices. Note that, in order to avoid 
arbitrary assumptions, the analysis is limited to the gross effects, ignoring the effect of expenditures potentially displaced by the climate finance disbursements. The assessment of net effects free of assumptions is possible using a retrospective approach when historical data on the actual transformations of the economy is available (as shown by Markandya et al., 2016).

\subsection{The database}

In order to apply this model two sets of data are required: 1) the GMRIO database, that provides information at industry level on production, technical coefficients, final demand and value-added for different countries; and 2) the data required to define the demand shock ( $\mathbf{f}^{\text {st }}$ in the model, see the Appendix) per climate action and recipient country.

From the various GMRIO databases (see Tukker \& Dietzenbacher, 2013), the World Input-Output Database (WIOD) is chosen. Two important advantages of WIOD are the following: first, it is public and freely available; and, second, it is based on national Supply and Use Tables (SUT), which contain information in terms of commodities that is required for the definition of the demand shocks. World InputOutput Tables (WIOT) from the WIOD combine information on national production activities for 59 products and 35 industries with international trade data for 40 countries (27 EU countries ${ }^{3}$ and 13 other major countries) for the period 1995-2011 (see Timmer et al. (2012) for further information on the database). The WIOD has certain weaknesses related to measurement issues ${ }^{4}$ and an important limitation for our analysis: the absence of least developed countries, where climate finance disbursements are most needed.

The analysis focuses on the most recent data (i.e. year 2011) and on all the countries included in the WIOD. Brazil, China, Indonesia, India and Mexico are considered climate finance recipient countries, and the rest of countries are considered donor countries. Donors are divided into four groups: USA, EU, EA (Japan, Korea and Taiwan) and other developed countries (ODC: Australia, Canada, Russia and Turkey). While this set does not include all countries, it represented approximately $84 \%$ of global GDP and $72 \%$ of global GHG emissions in 2011. The set of recipient countries 
represents around $60 \%$ of the emissions as well as GDP from developing countries in 2011 (World Bank Indicators).

Demand shocks are calculated for different types of climate actions using different sources of information. Following previous categorizations of climate action measures (Blazejczak, Braun, Edler, \& Schill, 2014; Buchner et al., 2013; OECD/IEA, 2014; Prowse \& Snilstveit, 2010; REN21, 2014, p. 21; UNFCCC, 2014b), 26 climate actions are considered, divided into three groups:

- Mitigation: This group consist of those actions with benefits in terms of GHG emissions reductions, including 14 renewable energy technologies (biogas power; biomass energy at large scale; biomass energy at small scale; concentrated solar power (CSP); deep geothermal energy; surface geothermal energy; hydropower; ocean power; offshore wind power; onshore wind power; photovoltaics; renewable energy in buildings; renewable energy in transport; solar thermal energy) and three energy efficiency measures (building insulation; energy efficiency in industry; transport infrastructures);

- Adaptation: This group consist of those actions that improve the resilience of societies, including measures in six sectors (coastal protection; disaster risk reduction; human settlements, infrastructure and spatial planning; social protection; waste and wastewater; water supply and management).

- Mitigation and adaptation (M\&A): This group contains three actions with benefits in both aspects (agriculture, fishing and livestock; capacity building; forestry and land use, terrestrial ecosystems).

For each climate action, a particular cost structure has to be determined. Cost structures consist of the distribution of the total costs of implementation of one action amongst the IO industries or commodities. Cost structures have to be defined in terms of the commodities classification of the SUT of WIOD (i.e. the Statistical Classification of Economic Activities in the European Community or NACE ${ }^{5}$ ). The cost structures of mitigation actions are taken from the literature: most renewable energy technologies from Lehr, Nitsch, Kratzat, Lutz, \& Edler (2008) and Lehr, Lutz, \& Edler (2012); ocean energy from Allan et al. (2008); renewable energy in transport and buildings and energy efficiency measures from Markaki et al. (2013). Detailed information at project level of 
National Adaptation Programmes of Action (NAPA) (UNFCCC, 2014b) is used for the definition of the cost structures of the rest of the climate actions. Since each climate action in adaptation comprises very different types of interventions, one particular NAPA project has been selected for each type, as shown in Table 1. The cost structure of each climate action is calculated as the average of the cost structures of the different types of interventions it comprises. The allocation of expenditures contained in NAPA projects to the commodity categories of the SUT is done following the correspondence in Table 2.

Figure 1 shows the obtained cost structures in terms of commodities, showing clearly the differences between the types of climate action envisaged. It shows, for example, that almost any type of project requires some construction work (commodity code 45), machinery (commodity code 29) and other business services (commodity code 74). On the contrary, only few actions, such as introducing biofuels in transport, require agricultural products (commodity code 1 ).

There is uncertainty regarding the cost structures defined for each climate action. The cost structure of renewable energy technologies depends on where and when the data on costs was gathered, due to differences in the costs of raw materials and labour, the different levels of commercial maturity of technologies, the evolution of global markets, etc. Adaptation projects or programs are very heterogeneous, and the site-specific circumstances influence costs. The approach proposed here can be used to undertake concrete case studies departing from data of particular projects, something that would enhance the accuracy of results. However, the ambition of this paper is to extract general conclusions about the sharing of economic benefits of climate finance that are not evident at first glance.

Obtained cost structures are based on cost data that include taxes and trade margins. Since the WIOT are expressed at basic prices (i.e. the amount actually received by producers), trade and transport margins and taxes need to be reallocated. WIOD International Supply Tables contain the information required to calculate tax and margins rates for each recipient country ${ }^{6}$ and commodity. The part of the expenditure corresponding to taxes is reallocated according to the government expenditure structure in each recipient country, which is calculated with information from the WIOD International Use Tables. The amount corresponding to trade margins (calculated with 
margins rates and the expenditure net of taxes) is reallocated according to the share of the total margins corresponding to each trade and transport service in each recipient country, which is calculated with information from the WIOD International Supply Tables.

Once the cost structures are expressed in basic prices, the next step is to differentiate where commodities are produced. Using the WIOD International Use Tables, the portion of the total demand that is produced domestically, along with the portion that is imported from all the other countries, are calculated for each recipient country and each commodity. Finally, the demands of each commodity and country are allocated to the WIOT industries according to market shares calculated with the information of the International Supply Tables. The resulting demand shocks $\left(\mathbf{f}^{\prime s t}\right)$ contain additional final demands, at basic prices, to different sectors (in different countries) that each climate action entails in each recipient country.

\section{Results}

Using this multiregional framework the amount of value-added generated by each country contributing (directly or indirectly) to the production of the goods and services needed for the climate actions is obtained. In this section, the research questions listed in the introduction are answered. Since impacts at the sector level are not the focus of this research, results are aggregated at country level.

\subsection{Geographic distribution of the value-added impact}

The first question is how the economic impacts caused by the implementation of climate actions are distributed between countries. Figure 2 displays the geographic distribution of the value-added impact of the 26 climate actions considered, depending on where climate finance is disbursed. For example, looking at the results for India, it can be seen that out of every USD 100 spent in climate actions in India, USD 80 remain in the Indian economy, China and the EU capture four USD each, the USA and ODC capture two USD each, EA countries capture one USD and the remaining seven USD go to the rest of the world (ROW).

On the one hand, the figure shows the differences in the ability of the economies of recipient countries to hold on to the value-added: in India and Brazil 
around $80 \%$ of the benefit remains within the domestic economy, but Mexico and Indonesia retain no more than two thirds. China is in an intermediate position among recipient countries, retaining $72 \%$ of the impact of its climate actions. On average, spillovers account for $28.6 \%$ of the total impact.

On the other hand, the ability of countries to attract spill-over effects also varies. The EU is the region that benefits most from international spill-overs in most cases. It captures $9 \%$ of the impacts generated when climate actions are implemented in China and $7 \%$ in the cases of Brazil, Indonesia and Mexico. It is also the donor that captures the highest share of spill-overs from India, where these are in any case very low for all donors. Note that the USA captures $15 \%$ of the impacts when climate actions are implemented in Mexico, but less than 3\% from other recipient countries. EA captures $6 \%$ of the impacts generated by climate actions in China and $5 \%$ in the case of Indonesia. In fact, EA captures more spill-overs than the USA in these two countries. China also substantially benefits from spill-overs independently of the destination of climate finance. Spill-overs attracted by China are among the largest when climate finance goes to India, Brazil and Indonesia. For example, China attracts more spillovers from India and Indonesia than the USA does, and a similar level of spill-overs from Brazil.

In order to clarify how impacts generated by climate finance are distributed among countries, consider the following example, illustrated in Figure 3: if each of the four donor countries (or group of countries) transferred one USD to a hypothetical GCF and this four USD fund was equally distributed among the five recipient countries, each of the donors would recover the following amounts in the form of spill-overs: USD 0.27 for the EU, USD 0.21 for the USA, USD 0.15 for EA and USD 0.08 for ODC. The amounts obtained by recipient countries would be USD 0.72 for China, USD 0.65 for India, USD 0.64 for Brazil, USD 0.53 for Indonesia and USD 0.49 for Mexico.

Figure 4 summarises the distribution of the value-added impacts of this hypothetical climate finance architecture. This example clearly shows that international trade redirects the value-added impacts from recipient countries to the countries that produce the inputs required for the deployment of climate actions. 


\subsection{Spill-overs by type of climate action}

So far, average impacts across a wide range of climate actions have been presented. But the geographical distribution of value-added is different for each type of climate action: some produce mainly domestic impacts whereas others generate a large proportion of spill-overs. Figure 5 shows the spill-overs associated with each type of investment on average for the considered recipient countries.

For example, out of every USD 100 spent in ocean power plants, USD 45 (on average for our set of recipient countries) go to countries different from the host country. Spill-overs range from $17 \%$ to $45 \%$. Several actions related to renewable energy sources (ocean power, solar thermal power, onshore wind, geothermal surface, hydropower and the introduction of renewable energy in buildings) produce spill-overs in excess of $35 \%$. The spill-overs from other renewable energy technologies (photovoltaics, small biomass, biogas and offshore wind), energy efficiency measures in industry, construction of infrastructures for transport and adaptation, disaster risk reduction actions and adaptation measures in the water sector range from $30 \%$ to $35 \%$. The spill-overs from some renewable energy technologies (CSP, large biomass, deep geothermal and biofuels), adaptation measures (waste management and social protection) and M\&A actions (agriculture and capacity building) range from $20 \%$ to $30 \%$. Finally, spill-overs of less than $20 \%$ are generated in the forestry sector, insulation of buildings and protection of coasts.

Table 3 presents for each type of action the portion of the impact that occurs in each country ${ }^{7}$. Figures for recipient countries reflect the percentage of impact that each one holds on to from domestic climate actions. For example, out of every USD 100 spent in capacity building projects in China, USD 78 remain in the Chinese economy. Figures for donor countries reflect the percentage of impact that each donor country attracts on average from the recipient countries considered. For example, the USA captures on average four USD out of every USD 100 spent in adaptation of the agriculture sector of the considered recipient countries. The figures do not add up to $100 \%$, since spill-overs captured by countries other than donors are not included. Recall that a significant share of the impact of climate actions in different recipient countries ends up in China, a fact that is not reflected in Table 3. 
This table clearly illustrates that measures with larger impacts on the economies of recipients offer limited benefits for donor countries in terms of spill-over effects. Depending on the type of action, the average domestic share of the impact ranges from $57 \%$ to $84 \%$ (see column 6 in Table 3). Differences exist depending on the regions where actions are implemented. Brazil and India retain between $68 \%$ and $89 \%$ of the relevant impacts, while Mexico holds on to between $39 \%$ and $83 \%$, depending on the type of action.

Average figures are included for broader categories of climate action (last four rows in Table 3). Depending on the recipient country, the domestic share of the impact of M\&A actions is between $76 \%$ and $86 \%$. Other adaptation measures and energy efficiency actions enable countries to hold on to between $64 \%$ and $82 \%$ of the impacts. Deployment of renewable energy sources of energy retains only between $53 \%$ and $77 \%$ of the impacts.

According to our results, the climate actions with the highest impact for recipient countries are the following: forestry sector and capacity building actions in the case of M\&A; coastal protection, social protection and waste management actions in the case of adaptation; building insulation in the case of energy efficiency; and the use of biofuels, deep geothermal, large biomass and CSP generation in the case of renewable energy.

Depending on the type of action, the average spill-overs that accrue to donor countries range from $2 \%$ to $7 \%$, with substantial differences between donors (last column in Table 3). Hence, depending on the donor country, renewable energy investments may provide spill-overs of between $2 \%$ and $8 \%$, energy efficiency measures and adaptation between $2 \%$ and $7 \%$ and M\&A actions between $1 \%$ and $5 \%$ (last four rows in Table 3). From the point of view of donor countries, the types of climate actions that result in a significant portion of impacts taking place in their economies are the following ones: ocean, wind, solar and hydropower for renewable energy sources; those in the industry sector and transport infrastructures for energy efficiency projects; actions in the water sector, infrastructures and disaster risk reduction measures for adaptation; and actions in the agriculture sector for M\&A. 
Although there is a common pattern for all countries included on the same side of the climate finance transfer (i.e. recipients or donors) regarding the effects of each type of action, there are slight variations. For example, India experiences a larger impact than the average recipient country due to the introduction of biofuels and water supply and management investments. China also stands out because of the size of the local impact of biofuels and photovoltaics. The same occurs with donors. For instance the EU stands out because of the size of the spill-overs received from ocean power investments.

\subsection{Spill-overs by donor country and disbursement option}

In the previous section, spill-overs by donor country, given as average, did not enable to distinguish differences caused by the location where actions are implemented. The size of spill-overs captured by a donor country depends not only on the type of climate action, but also on the recipient country where it is undertaken. Table 4 gathers the results relative to the portion of spill-overs that each donor country can expect from climate-related expenditures in the different recipient countries ${ }^{8}$. To rank climate finance disbursement alternatives according to potential of value-added spill-overs, this table could help to identify the best options for each donor country.

The USA benefits especially from climate projects in Mexico, regardless of their type, as it captures between 7\% (coastal protection) and 24\% (ocean energy) of the total impact in the form of spill-overs. Other investment options that offer good returns to the USA are ocean energy projects in Brazil and Indonesia and onshore wind projects in Brazil (5\% each). China is the country that generates the largest spill-overs for the EU and ODC. The action that offers the largest spill-overs for the EU is ocean power in China and in Mexico (13\%). Indonesia, Mexico and Brazil offer spill-overs of 7\% on average for the EU. ODC's best options are small biomass projects in China (5\%), ocean power and onshore wind in Mexico (4\%) and ocean power in Indonesia (4\%). EA benefits especially from ocean energy and surface geothermal investments in Indonesia (11\%), but also from several types of projects in China and Mexico (7\%).

Several combinations of location/type of action have a very limited potential to generate spill-overs for donors. Cases with average spill-overs below $2 \%$ include most climate actions in India, several in Brazil (social protection, renewable energy in 
transport, capacity building and forest adaptation, building insulation and coastal protection), and building insulation and coastal protection in Indonesia.

\section{Discussion}

Results show that the stimulus generated by climate-related expenditures is shared out between the recipient country and other economies, including donor countries, due to international trade. This fact may have implications for both donors and recipients when making decisions about climate finance allocation.

From the point of view of a potential donor, as long as its ability to capture spill-overs is substantial, contributing to climate finance might be a way to stimulate exports and growth. Since the size of potential benefits differs from one donor to another, as results on spill-overs show, the influence of this factor on climate finance decisions might also vary.

Despite that spill-overs might currently be only receiving marginal attention from the donors, it is remarkable that those donors benefitting from significant spillovers are also major contributors to climate funds (i.e. UK, USA, Germany and Japan). The great ability of China to capture spill-overs may also be somehow related to the prominence of China as donor in South-South cooperation. In fact, China does not hide the fact that foreign aid is seen as a way to expand exports (Minas, 2014; The Climate Group, 2013).

Our results indicate the potential of each type of action and alternative location for generating spill-over effects via demand for donors' industries products. The group of measures that produce the largest spill-overs includes several mitigation and adaptation options requiring goods with high technology content that are not usually produced domestically in many recipient countries, such as machinery (commodity code 29), electrical, communication and precision equipment (commodities code 31-33) and motor vehicles (commodity code 34 ).

So far, investments in the energy sector have been a priority in the use of climate finance (UNFCCC, 2014a). According to our results, this may have produced substantial spill-overs for donors. Agriculture and water, the main sectors receiving finance for adaptation, are also associated with the generation of substantial spill-overs 
due to the requirements of machinery (commodity code 29) and research and development services (commodity code 73) (see Figure 1). Asia and the Pacific region (including two recipients that generate large spill-overs, such as China and Indonesia) are the main recipients of past climate finance. This would suggest that the search for spill-overs has been one of the factors determining the international allocation of climate finance. However, a significant proportion of funds has been used for mitigation in the forestry sector in Latin America, a fact that would not be consistent with the prospects of spill-over effects.

On the other hand, projects that are most able to stimulate recipient countries' economies are those intensive in locally produced services like construction work (commodity code 45) and other business services (commodity code 74), as is the case for many adaptation options. Allocating the same priority to support for adaptation as to mitigation has recently become a core element rather than a peripheral issue in the United Nations' climate talks, especially due to developing countries' demands (Fridahl \& Linnér, 2015; Galarraga \& Román, 2013, 2015; GCF, 2014). This position in favour of increased support for adaptation by developing countries would make sense from the perspective of trying to increase the local impact of climate finance disbursements.

To sum up, the donor's bias towards funding renewable energy projects and the developing countries' demand for more funding for adaptation would be consistent with the economic interests of each group of countries', in the light of our results. Results also provide insights about an additional aspect that should be borne in mind when assessing alternative investment options from the point of view of both donors and recipients.

Our results reinforce the idea that the impacts of climate finance are best assessed on a global scale, and demonstrate the potential of GMRIO databases as tools for analysing economy-wide impacts of climate finance. However, the already mentioned shortcomings of the IO method apply here too. Recall also that our assessment only considers the positive short-term effects associated with new expenditures, but does not account for other impacts on the medium/long term associated with potential displaced expenditures, changes in prices or income. Furthermore, we only explore the "ancillary" economic impacts of climate finance, in the sense that we do not account for the direct economic benefits of mitigation and 
adaptations in terms of avoided impacts (which is the ultimate objective of climate finance),

There are several ways to extend the present research: first, by broadening the scope of analysis to include additional countries. Our analysis only considers five major recipient countries. This might lead to an underestimation of the size of spill-over effects, since it has already been argued that small countries generate more spill-overs (see, for example, Dietzenbacher, Guilhoto, et al., 2013).

This connects with a second possible extension of our research: identifying factors that can explain the results. Despite the fact that all recipient countries considered are big economies, Table 3 shows differences in the abilities of these countries to retain the impacts of similar types of investment. Apart from size, Dietzenbacher et al. (2013) point to the openness of economies to explain the size of spill-overs. The small spill-overs generated by Brazil could thus be a consequence of the big size of its economy and the low dependency on imports (a result that the said authors corroborate in the paper cited). Beutel (2003) points to two additional factors: development level and competitiveness. In fact, competitiveness might provide an explanation of results for Mexico: despite the big size of the Mexican economy, its weaker competitive position in relation to the USA economy could explain the size of the spill-overs between the two countries. Competitiveness might also help us understand why EU countries and the USA, among the donors, and China, among the recipients, are where most relevant spill-overs occur 9 . Other factors that could be included in the study of the determinants of the magnitude of spill-overs are the productive specialization and geographical location.

As previously explained, value-added includes labour remuneration and capital compensation. Thus, one part of the impact accrues to workers and the rest to owners of capital. According to Timmer et al. (2014) from 1995 to 2008 the capital share of valueadded has increased globally, but especially in emerging countries such as China, India, Brazil and Mexico. Given the sizeable foreign investment flows, it can be imagined that a significant part of the domestic impact of climate actions in emerging regions is in the form of revenues of multinational companies, whose headquarters are in the most economically advanced regions. Our results do not enable to observe these kind of spillovers. So, a third possible extension of this paper would consist of separating labour and 
capital impacts, and within the latter differentiate the part corresponding to foreign capital.

\section{Conclusions}

Studies assessing the economic impacts of climate-related expenditures at the national level have noted the relevant role of international trade. For instance, Lehr et al. (2008) conclude that if low-carbon technologies create employment in Germany, this is due to exports. Other studies also show that the ability to retain economic gains depends on the share of components that can be manufactured domestically (Ciorba et al., 2004; Markaki et al., 2013; Oliveira et al., 2013). These previous findings point to the relative position of economies in international markets as a factor in determining the economic gains from climate investments.

Our results confirm that international trade has an important role in the distribution of the economic benefits of climate finance. While the largest portion of the value-added generated by climate actions is domestic (71\% on average), a significant share $(29 \%$ on average) spills over to other economies. Spill-overs accruing to the considered donor countries range from $10 \%$ to $28 \%$, depending on the climate actions implemented and the location.

The magnitude of the spill-overs varies with the nature of the project. Deployment of renewable energy technologies generates large spill-over effects, while M\&A actions produce substantial domestic impact and limited spill-overs. The type of actions that offer recipient countries the best opportunities to grow do not coincide with those that benefit donor countries in the form of spill-overs. Nevertheless, there are some mitigation and adaptation options that involve substantial benefits in terms of value-added in both donor and recipient countries (i.e. renewable energy sources like CSP and offshore wind, infrastructures for transport and adaptation, and water supply and management projects).

While renewable energy deployment is the type of intervention with better return in terms of spill-overs for all donors, some differences have been identified. The USA benefits from substantial spill-overs from any type of climate project that is implemented in Mexico. Largest spill-overs to the EU come from renewable energy projects implemented in China and Mexico. ODC benefit similarly from renewable 
energy investments in China, Mexico and Indonesia, while EA benefits especially from renewable energy in Indonesia.

Several climate actions have been identified that might be unlikely to find funding opportunities if donors made their decisions exclusively based on the prospects of capturing value-added impacts. This is the case of coastal protection in Indonesia, where two million people are exposed to rising sea level rise (IPCC, 2001). In these specific situations the international community should implement mechanisms to ensure that sufficient climate financial flows reach the most vulnerable regions.

Even though the main purpose of climate finance is enabling climate action in recipient countries, the study of the economic impact of climate finance disbursements provides useful insights on how country-driven climate strategies may make a major contribution not only to low carbon development and climate change adaptation, but also to overall economic development. The current analysis has therefore focused on the opportunities of the transition towards decarbonised and resilient societies although, in future developments, it could be used to complement this assessment of economic benefits with the estimation of mitigation potential of financed climate actions.

Taking into account that the long-term finance commitments of higher-income countries under the United Nations' Climate talks entail reaching USD 100 billion per year by $2020^{10}$, spill-over effects may add up to several billion USD per year. Thus, our results constitute valuable information for governments to help them understand the economic consequences of decisions about climate finance allocation. For example, our results suggest that correcting the current bias towards mitigation in climate finance flows would not only enhance developing countries' climate resilience, but also contribute to their economic growth.

Finally, our findings may help aligning mitigation and adaptation to climate change with industrial policy. Thus, our results suggest that some recipient countries have significant room for manoeuvre for improving their ability to retain the valueadded generated by capital-intensive projects, such as those involving renewable energy technologies. Such projects require machinery, transportation and communication equipment, and mineral and metal inputs that must typically be brought from abroad. Thus, in order to maximise the domestic impact of climate finance, recipient countries 
could pursue strategies aimed at improving the competitiveness of their industrial sectors. Technology transfer programmes may also enhance the ability of these countries to decrease their dependency on imports of capital goods that generate relevant spill-overs. As long as such programmes help to build up competitive industries that can provide substitutes for the imported goods, the domestic impact of climate finance may multiply.

\section{Notes}

[1] Accounting for the current pledges according to the web site Climate Funds Update (2016).

[2] For example, Timmer et al. (2014) using the GMRIO framework show that the process of international production fragmentation is pervasive: between 1995 and 2008 the content of foreign value-added in manufactures increased in $85 \%$ of the examined goods.

[3] In the WIOD and in this paper UK is still considered a Member State of the European Union.

[4] For a detailed description of the WIOD project, the WIOT and main weaknesses see Dietzenbacher, Los, Stehrer, Timmer, \& de Vries (2013), Timmer et al. (2012) and Timmer, Dietzenbacher, Los, Stehrer, \& de Vries (2015).

[5] Table A.1. in the Appendix displays the NACE classification of commodities. NACE stands for Nomenclature statistique des activités économiques dans la Communauté européenne

[6] Since this information is not available for two recipient countries (China and Indonesia), average values of the other recipient countries (Brazil, India and Mexico) are used instead.

[7] Figures for recipient countries (columns 1-5) reflect the percentage of impact that is retained by each country when it receives climate finance. Figures for donor countries (columns 7-10) reflect the percentage of impact that each donor country attracts on average when climate finance is disbursed to the recipient countries considered. The colour scale reflects the attractiveness of each climate action for each country (from the 
point of view of its potential for creating domestic impacts in the case of recipient countries, and spill-overs in the case of donors). So, the colour scale ranks values column-wise. The most attractive options are in darker tones and the least attractive ones in lighter tones. The table is sorted by the value of column 6 (Average Recipient) in descending order.

[8] The colour scale reflects the attractiveness of each climate action for each donor country (from the point of view of its potential for creating spill-overs). So, the colour scale ranks the values referred to one donor (including different climate actions in different locations). The most attractive options are in darker tones and the least attractive ones in lighter tones.

[9] Six European countries, the USA and Japan were in the top-ten global competitiveness ranking 2011-2012. China occupies the highest position amongst the BRICS, and Mexico is in 58st place out of 144 in the global ranking (Schwab, 2011).

[10] This amount is similar to the level of total net official development assistance and official aid received in 2005: 108.45 USD billions (The World Bank, 2016). 


\section{References}

Abadie, L. M., Galarraga, I., \& Rübbelke, D. (2013). An analysis of the causes of the mitigation bias in international climate finance. Mitigation and Adaptation Strategies for Global Change, 18(7), 943-955. https://doi.org/10.1007/s11027012-9401-7

Allan, G. J., Bryden, I., McGregor, P., Stallard, T., Swales, J. K., Turner, K., \& Wallace, R. (2008). Concurrent and legacy economic and environmental impacts from establishing a marine energy sector in Scotland. Energy Policy, 36(7), 2734-2753. https://doi.org/10.1016/j.enpol.2008.02.020

Arto, I., Amores, A., \& Rueda-Cantuche, J. M. (2015). Measuring the intra-EU employment driven by the EU exports to the rest of the world. In The Sustainability Practitioner's Guide to Social Analysis, Assessment and Reporting. (1st ed., p. 239). Champaign, Illinois, USA: Common Ground Publishing.

Basu, P., Finneran, L., Bishop, V., \& Sundararaman, T. (2011). The Scope for MDB Leverage and Innovation in Climate Finance. Background paper for Mobilizing Climate Finance, prepared at the request of G20 Finance Ministers. Retrieved from https://www.imf.org/external/np/g20/pdf/110411c.pdf

Beutel, J. (2003). The economic impact of objective 1 inteventions for the period 20002006. Fachhochschule Konstanz/Wirtschafts-und Sozialwissenschaften (WS). Retrieved from http://www.dgfc.sepg.minhap.gob.es/sitios/dgfc/esES/ei/er/ie/Documents/ImpactoFFEERegO1_2000_2006_Beutel.pdf

Blazejczak, J., Braun, F. G., Edler, D., \& Schill, W.-P. (2014). Economic effects of renewable energy expansion: A model-based analysis for Germany. Renewable 
and Sustainable Energy Reviews, 40, 1070-1080.

https://doi.org/10.1016/j.rser.2014.07.134

Buchner, B., Herve-Mignucci, M., Trabacchi, C., Wilkinson, J., Stadelmann, M., Boyd, R., ... Micale, V. (2013). Global Landscape of Climate Finance 2013. Climate Policy Initiative. Retrieved from http://climatepolicyinitiative.org/publication/global-landscape-of-climatefinance-2013/

Buchner, B., Trabacchi, C., Mazza, F., Abramskiehn, D., \& Wang, D. (2015). Global Landscape of Climate Finance 2015. Climate Policy Initiative. Retrieved from http://climatepolicyinitiative.org/wp-content/uploads/2015/11/GlobalLandscape-of-Climate-Finance-2015.pdf

Caldés, N., Varela, M., Santamaría, M., \& Sáez, R. (2009). Economic impact of solar thermal electricity deployment in Spain. Energy Policy, 37(5), 1628-1636. https://doi.org/10.1016/j.enpol.2008.12.022

Ciorba, U., Pauli, F., \& Menna, P. (2004). Technical and economic analysis of an induced demand in the photovoltaic sector. Energy Policy, 32(8), 949-960. https://doi.org/10.1016/S0301-4215(03)00018-1

Dietzenbacher, E., Guilhoto, J., \& Imori, D. (2013). The role of Brazilian regions in the global value chain (Working Paper Series N ${ }^{0}$ 2013-15). Department of Economics-FEA/USP. Retrieved from http://papers.ssrn.com/sol3/papers.cfm?abstract_id=2402274

Dietzenbacher, E., Los, B., Stehrer, R., Timmer, M., \& De Vries, G. (2013). The construction of world input-output tables in the WIOD project. Economic Systems Research, 25(1), 71-98. https://doi.org/10.1080/09535314.2012.761180 
Francois, J., Manchin, M., \& Tomberger, P. (2015). Services linkages and the value added content of trade. The World Economy, 38(11), 1631-1649. https://doi.org/10.1111/twec. 12307

Fridahl, M., \& Linnér, B.-O. (2015). Perspectives on the Green Climate Fund: possible compromises on capitalization and balanced allocation. Climate and Development, 8(2), 105-109. https://doi.org/10.1080/17565529.2015.1040368

Galarraga, I., \& Román, M. V. (2013). Warsaw Conference: "Small steps forward while awaiting major decisions at the 2015 Paris Conference” (No. PB 2013/ Special Issue-01). BC3 Basque Centre for Climate Change. Retrieved from http://www.bc3research.org/policybriefings/2013-SpecialIssue-01

Galarraga, I., \& Román, M. V. (2015). Lima COP20: Another small step on the long road to Paris (No. 2015-1). BC3 Basque Centre for Climate Change. Retrieved from http://www.bc3research.org/policybriefings/2015-01/specialissue

GCF. (2014). Policies and Procedures for the Initial Allocation of Fund Resources (Meeting of the Board No. GCF/B.06/05). Bali, Indonesia: Green Climate Fund. Retrieved from https://www.greenclimate.fund/documents/20182/24940/GCF_B.06_05__Policies_and_Procedures_for_the_Initial_Allocation_of_Fund_Resources.pdf/c 58faf81-d780-4918-94d4-407a49af501e?version=1.1

GCF. (2016). Pledge Tracker - Green Climate Fund. Retrieved January 10, 2017, from http://www.greenclimate.fund/contributions/pledge-tracker

Gupta, S., Harnisch, J., Barua, D. C., Chingambo, L., Frankel, P., Garrido Vázquez, R. J., ... Massetti, E. (2014). Cross-cutting Investment and Finance Issues. In Climate Change 2014: Mitigation of Climate Change. Contribution of Working Group III to the Fifth Assessment Report of the Intergovernmental Panel on 
Climate Change. [Edenhofer, O., R. Pichs-Madruga, Y. Sokona, E. Farahani, S.

Kadner, K. Seyboth, A. Adler, I. Baum, S. Brunner, P. Eickemeier, B. Kriemann, J. Savolainen, S. Schlömer, C. von Stechow, T. Zwickel and J.C. Minx (eds.)]. Cambridge, United Kingdom and New York, NY, USA.: Cambridge University Press.

Halimanjaya, A. (2015). Climate mitigation finance across developing countries: what are the major determinants? Climate Policy, 15(2), 223-252. https://doi.org/10.1080/14693062.2014.912978

Han, S.-Y., Yoo, S.-H., \& Kwak, S.-J. (2004). The role of the four electric power sectors in the Korean national economy: an input-output analysis. Energy Policy, 32(13), 1531-1543. https://doi.org/10.1016/S0301-4215(03)00125-3

Herreras Martínez, S., van Eijck, J., Pereira da Cunha, M., Guilhoto, J. J. M., Walter, A., \& Faaij, A. (2013). Analysis of socio-economic impacts of sustainable sugarcane-ethanol production by means of inter-regional Input-Output analysis: Demonstrated for Northeast Brazil. Renewable and Sustainable Energy Reviews, 28, 290-316. https://doi.org/10.1016/j.rser.2013.07.050

Hienuki, S., Kudoh, Y., \& Hondo, H. (2015). Life cycle employment effect of geothermal power generation using an extended input-output model: the case of Japan. Journal of Cleaner Production, 93, 203-212. https://doi.org/10.1016/j.jclepro.2015.01.008

IEA. (2014). Energy Technology Perspectives 2014. Harnessing Electricity's Potential. Executive Summary. International Energy Agency. Retrieved from http://www.iea.org/Textbase/npsum/ETP2014SUM.pdf

IMF. (2011). Promising Domestic Fiscal Instruments for Climate Finance. Background Paper for the Report to the G20 on-Mobilizing Sources of Climate Finance. 
1

2

3

4

5

6

7

8

10

International Monetary Fund. Retrieved from

https://www.imf.org/external/np/g20/pdf/110411b.pdf

IPCC. (2001). Potential Impacts and Coastal Zone Management. Retrieved August 24, 2016, from http://www.ipcc.ch/ipccreports/tar/wg2/index.php?idp=446

Johnson, R. C., \& Noguera, G. (2012). Accounting for intermediates: Production sharing and trade in value added. Journal of International Economics, 86(2), 224-236. https://doi.org/10.1016/j.jinteco.2011.10.003

Jones, B., Keen, M., \& Strand, J. (2013). Fiscal implications of climate change. International Tax and Public Finance, 20(1), 29-70. https://doi.org/10.1007/s10797-012-9214-3

Koopman, R., Wang, Z., \& Wei, S.-J. (2012). Estimating domestic content in exports when processing trade is pervasive. Journal of Development Economics, 99(1), 178-189. https://doi.org/10.1016/j.jdeveco.2011.12.004

Koopman, R., Wang, Z., \& Wei, S.-J. (2014). Tracing value-added and double counting in gross exports. The American Economic Review, 104(2), 459-494. https://doi.org/10.1257/aer.104.2.459

Lehr, U., Lutz, C., \& Edler, D. (2012). Green jobs? Economic impacts of renewable energy in Germany. Energy Policy, 47, 358-364. https://doi.org/10.1016/j.enpol.2012.04.076

Lehr, U., Nitsch, J., Kratzat, M., Lutz, C., \& Edler, D. (2008). Renewable energy and employment in Germany. Energy Policy, 36(1), 108-117.

Los, B., Timmer, M. P., \& de Vries, G. J. (2015). Tracing Value-Added and Double Counting in Gross Exports: Comment. American Economic Review, 106(7), 1958-66. https://doi.org/10.1257/aer.20140883 
Markaki, M., Belegri-Roboli, A., Michaelides, P., Mirasgedis, S., \& Lalas, D. P. (2013). The impact of clean energy investments on the Greek economy: An input-output analysis (2010-2020). Energy Policy, 57, 263-275. https://doi.org/10.1016/j.enpol.2013.01.047

Markandya, A., Arto, I., González-Eguino, M., \& Román, M. V. (2016). Towards a green energy economy? Tracking the employment effects of low-carbon technologies in the European Union. Applied Energy, 179, 1342-1350. https://doi.org/10.1016/j.apenergy.2016.02.122

Miller, R. E., \& Blair, P. D. (2009). Input-output analysis: foundations and extensions. Cambridge University Press.

Minas, S. (2014). FPC Briefing: Climate Change Cooperation within the Global South: Finance, Policy and Institutions. The Foreign Policy Centre. Retrieved from http://fpc.org.uk/fsblob/1628.pdf

Nagengast, A. J., \& Stehrer, R. (2016). Accounting for the Differences Between Gross and Value Added Trade Balances. The World Economy, 39(9), 1276-1306. https://doi.org/10.1111/twec.12401

Nakhooda, S., Fransen, T., Kuramochi, T., \& Caravani, A. (2013). Mobilising International Climate Finance: Lessons from the Fast-Start Finance Period. ODI, WRI, IGES, OCN, UKAid. Retrieved from https://www.odi.org/sites/odi.org.uk/files/odi-assets/publications-opinionfiles/8687.pdf

Neuwahl, F., Löschel, A., Mongelli, I., \& Delgado, L. (2008). Employment impacts of EU biofuels policy: combining bottom-up technology information and sectoral market simulations in an input-output framework. Ecological Economics, 68(1), 447-460. https://doi.org/10.1016/j.ecolecon.2008.04.018 
OECD, \& CPI. (2015). Climate Finance in 2013-14 and the USD 100 billion goal. A report by the Organization for Economic Co-operation and Development (OECD) in collaboration with Climate Policy Initiative (CPI). Retrieved from http://www.oecd.org/environment/cc/OECD-CPI-Climate-Finance-Report.htm

OECD/IEA. (2014). Tracking Clean Energy Progress 2014. IEA, International Energy Agency. Retrieved from http://www.iea.org/publications/freepublications/publication/Tracking_clean_en ergy_progress_2014.pdf

Oliveira, C., Coelho, D., da Silva, P. P., \& Antunes, C. H. (2013). How many jobs can the RES-E sectors generate in the Portuguese context? Renewable and Sustainable Energy Reviews, 21, 444-455.

Parker, C., Brown, J., Pickering, J., Roynestad, E., Mardas, N., \& Mitchell, A. (2010). The little climate finance book: A guide to financing options for forests and climate change. Global Canopy Foundation. Retrieved from https://www.odi.org/sites/odi.org.uk/files/odi-assets/publications-opinionfiles/5640.pdf

Pickering, J., \& Rübbelke, D. (2014). International Cooperation on Adaptation to Climate Change. In A. Markandya, I. Galarraga, \& E. Sainz de Murieta (Eds.), Handbook of the Economics of Climate Change Adaptation (pp. 86-106). Abingdon (UK): Routledge.

Pickering, J., Skovgaard, J., Kim, S., Reich, H., Roberts, J. T., Rosatti, D., \& Stadelmann, M. (2015). Acting on Climate Finance Pledges: Inter-Agency Dynamics in Contributor States. World Development, 68, 149-162. https://doi.org/10.1016/j.worlddev.2014.10.033 
Pittel, K., \& Rübbelke, D. (2013). International climate finance and its influence on fairness and policy. The World Economy, 36(4), 419-436. https://doi.org/10.1111/twec.12029

Prowse, M., \& Snilstveit, B. (2010). Impact evaluation and interventions to address climate change: a scoping study. Journal of Development Effectiveness, 2(2), 228-262. https://doi.org/10.1080/19439341003786729

REN21. (2014). Renewables 2014. Global status report. Paris: REN21 Secretariat: Renewable Energy Policy Network for the 21sr Century. Retrieved from http://www.ren21.net/Portals/0/documents/Resources/GSR/2014/GSR2014_full \%20report_low\%20res.pdf

Rübbelke, D. T. G. (2011). International support of climate change policies in developing countries: Strategic, moral and fairness aspects. Ecological Economics, 70, 1470-1480. https://doi.org/10.1016/j.ecolecon.2011.03.007

Schwab, K. (2011). The Global Competitiveness Report 2011-2012. Geneva, Switzerland: World Economic Forum. Retrieved from http://www3.weforum.org/docs/WEF_GCR_Report_2011-12.pdf

Scott, M. J., Roop, J. M., Schultz, R. W., Anderson, D. M., \& Cort, K. A. (2008). The impact of DOE building technology energy efficiency programs on U.S. employment, income and investment. Energy Economics, 30, 2283-2301. https://doi.org/10.1016/j.eneco.2007.09.001

The Climate Group. (2013). Shaping China's Climate Finance Policy (Insight briefing). The Climate Group. Retrieved from https://www.theclimategroup.org/sites/default/files/archive/files/ShapingChinas-Climate-Finance-Policy.pdf 
The World Bank. (2016). Net official development assistance and official aid received (current US\$). Retrieved July 27, 2016, from http://data.worldbank.org/indicator/DT.ODA.ALLD.CD

Timmer, M., Erumban, A. A., Gouma, R., Los, B., Temurshoev, U., de Vries, G. J., ... others. (2012). The world input-output database (WIOD): contents, sources and methods (Working Paper No. 10). Institute for International and Development Economics. Retrieved from http://www.wiod.org/publications/papers/wiod10.pdf

Timmer, M. P., Dietzenbacher, E., Los, B., Stehrer, R., \& Vries, G. J. (2015). An illustrated user guide to the world input-output database: the case of global automotive production. Review of International Economics, 23(3), 575-605. https://doi.org/10.1111/roie. 12178

Timmer, M. P., Erumban, A. A., Los, B., Stehrer, R., \& de Vries, G. J. (2014). Slicing up global value chains. The Journal of Economic Perspectives, 28(2), 99-118. https://doi.org/10.1257/jep.28.2.99

Tourkolias, C., \& Mirasgedis, S. (2011). Quantification and monetarization of employment benefits associated with renewable energy technologies in Greece. Renewable and Sustainable Energy Reviews, 15, 2876-2886. https://doi.org/10.1016/j.rser.2011.02.027

Tukker, A., \& Dietzenbacher, E. (2013). Global multiregional input-output frameworks: an introduction and outlook. Economic Systems Research, 25(1), 1-19. https://doi.org/10.1080/09535314.2012.761179

UNEP. (2014). The Adaptation Gap Report 2014. Nairobi, Kenya: United Nations Environment Programme (UNEP). Retrieved from 
http://www.unep.org/climatechange/adaptation/gapreport2014/portals/50270/pdf

\section{/AGR_FULL_REPORT.pdf}

UNFCCC. (2009). FCCC/CP/2009/L.7. Copenhagen Accord. Retrieved from http://unfecc.int/resource/docs/2009/cop15/eng/107.pdf

UNFCCC. (2010). UNFCCC Decision 1/CP.16. The Cancun Agreements. Retrieved from http://unfccc.int/resource/docs/2010/cop16/eng/07a01.pdf

UNFCCC. (2014a). 2014 Biennial Assessment and Overview of Climate Finance Flows Report. United Nations Framework Convention on Climate Change (UNFCCC). Retrieved from http://unfccc.int/files/cooperation_and_support/financial_mechanism/standing_c ommittee/application/pdf/2014_biennial_assessment_and_overview_of_climate _finance_flows_report_web.pdf

UNFCCC. (2014b). NAPAs received by the secretariat. Retrieved August 24, 2016, from http://unfecc.int/adaptation/workstreams/national_adaptation_programmes_of_a ction/items/4583.php

UNFCCC. (2015). Adoption of the Paris Agreement. Proposal by the President. Draft decision -/CP.21. FCCC/CP/2015/L.9. Retrieved from http://unfecc.int/resource/docs/2015/cop21/eng/109.pdf

Ziegelmann, A., Mohr, M., \& Unger, H. (2000). Net employment effects of an extension of renewable-energy systems in the Federal Republic of Germany. Applied Energy, 65(1-4), 329-338. https://doi.org/10.1016/S03062619(99)00072-0 


\section{Appendix}

\section{Table A.1. NACE classification of commodities}

\begin{tabular}{|c|c|}
\hline Code & Description \\
\hline 1 & Products of agriculture, hunting and related services \\
\hline 2 & Products of forestry, logging and related services \\
\hline 5 & Fish and other fishing products; services incidental of fishing \\
\hline 10 & Coal and lignite; peat \\
\hline 11 & Crude petroleum and natural gas; services incidental to oil and gas extraction excluding surveying \\
\hline 12 & Uranium and thorium ores \\
\hline 13 & Metal ores \\
\hline 14 & Other mining and quarrying products \\
\hline 15 & Food products and beverages \\
\hline 16 & Tobacco products \\
\hline 17 & Textiles \\
\hline 18 & Wearing apparel; furs \\
\hline 19 & Leather and leather products \\
\hline 20 & Wood and products of wood and cork (except furniture); articles of straw and plaiting materials \\
\hline 21 & Pulp, paper and paper products \\
\hline 22 & Printed matter and recorded media \\
\hline 23 & Coke, refined petroleum products and nuclear fuels \\
\hline 24 & Chemicals, chemical products and man-made fibres \\
\hline 25 & Rubber and plastic products \\
\hline 26 & Other non-metallic mineral products \\
\hline 27 & Basic metals \\
\hline 28 & Fabricated metal products, except machinery and equipment \\
\hline 29 & Machinery and equipment not elsewhere classified (n.e.c.) \\
\hline 30 & Office machinery and computers \\
\hline 31 & Electrical machinery and apparatus n.e.c. \\
\hline 32 & Radio, television and communication equipment and apparatus \\
\hline 33 & Medical, precision and optical instruments, watches and clocks \\
\hline 34 & Motor vehicles, trailers and semi-trailers \\
\hline 35 & Other transport equipment \\
\hline 36 & Furniture; other manufactured goods n.e.c. \\
\hline 37 & Secondary raw materials \\
\hline 40 & Electrical energy, gas, steam and hot water \\
\hline 41 & Collected and purified water, distribution services of water \\
\hline 45 & Construction work \\
\hline 50 & Trade, maintenance and repair services of motor vehicles and motorcycles; retail sale of automotive fuel \\
\hline 51 & Wholesale trade and commission trade services, except of motor vehicles and motorcycles \\
\hline 52 & $\begin{array}{l}\text { Retail trade services, except of motor vehicles and motorcycles; repair services of personal and household } \\
\text { goods }\end{array}$ \\
\hline 55 & Hotel and restaurant services \\
\hline 60 & Land transport; transport via pipeline services \\
\hline 61 & Water transport services \\
\hline 62 & Air transport services \\
\hline 63 & Supporting and auxiliary transport services; travel agency services \\
\hline 64 & Post and telecommunication services \\
\hline 65 & Financial intermediation services, except insurance and pension funding services \\
\hline 66 & Insurance and pension funding services, except compulsory social security services \\
\hline 67 & Services auxiliary to financial intermediation \\
\hline 70 & Real estate services \\
\hline 71 & Renting services of machinery and equipment without operator and of personal and household goods \\
\hline 72 & Computer and related services \\
\hline 73 & Research and development services \\
\hline 74 & Other business services \\
\hline 75 & Public administration and defence services; compulsory social security services \\
\hline 80 & Education services \\
\hline
\end{tabular}




\begin{tabular}{|l|l|}
\hline 85 & Health and social work services \\
\hline 90 & Sewage and refuse disposal services, sanitation and similar services \\
\hline 91 & Membership organisation services n.e.c. \\
\hline 92 & Recreational, cultural and sporting services \\
\hline 93 & Other services \\
\hline 95 & Private households with employed persons \\
\hline
\end{tabular}

\section{Structure of the multiregional IO model}

The structure of a multiregional IO model is illustrated with the example of a threecountry model. It consists of a system of linear equations that describe the relation between inputs and final products in each sector. In this case, the standard demanddriven model can be written as $\mathbf{x}=(\mathbf{I}-\mathbf{A})^{-1} \mathbf{F}=\mathbf{L F}$

With $\mathbf{x}=\left(\begin{array}{l}\mathbf{x}^{1} \\ \mathbf{x}^{2} \\ \mathbf{x}^{3}\end{array}\right), \quad \mathbf{I}=\left(\begin{array}{lll}1 & 0 & 0 \\ 0 & 1 & 0 \\ 0 & 0 & 1\end{array}\right), \quad \mathbf{A}=\left(\begin{array}{lll}\mathbf{A}^{11} & \mathbf{A}^{12} & \mathbf{A}^{13} \\ \mathbf{A}^{21} & \mathbf{A}^{22} & \mathbf{A}^{23} \\ \mathbf{A}^{31} & \mathbf{A}^{32} & \mathbf{A}^{33}\end{array}\right), \quad \mathbf{F}=\left(\begin{array}{lll}\mathbf{f}^{11} & \mathbf{f}^{12} & \mathbf{f}^{13} \\ \mathbf{f}^{21} & \mathbf{f}^{22} & \mathbf{f}^{23} \\ \mathbf{f}^{31} & \mathbf{f}^{32} & \mathbf{f}^{33}\end{array}\right)$ and $\mathbf{L}=\left(\begin{array}{ccc}\mathbf{L}^{11} & \mathbf{L}^{12} & \mathbf{L}^{13} \\ \mathbf{L}^{21} & \mathbf{L}^{22} & \mathbf{L}^{23} \\ \mathbf{L}^{31} & \mathbf{L}^{32} & \mathbf{L}^{33}\end{array}\right)$

Where $\mathbf{x}^{r}$ is the column vector of gross outputs in country $\mathrm{r}$ with elements $x_{i}^{r}$ indicating the production in country r of products of sector i. $\mathbf{I}$ is an identity matrix of the appropriate dimension (in this case, three). $\mathbf{A}^{r s}$ is the matrix of input coefficients calculated as $\mathbf{A}^{r s}=\mathbf{Z}^{r s}\left(\hat{\mathbf{x}}^{s}\right)^{-1}$, where $\mathbf{Z}^{r s}$ is the matrix of intermediate inputs from country $\mathrm{r}$ to country $\mathrm{s}$, with elements $z_{i j}^{r s}$ indicating the sales of sector $\mathrm{i}$ in country $\mathrm{r}$ to sector $\mathrm{j}$ in country $\mathrm{s}$ and $\left(\hat{\mathbf{x}}^{r}\right)^{-1}$ is the inverse of the diagonal matrix of the gross outputs vector. $(\mathbf{I}-\mathbf{A})^{-1}$ is also known as the matrix of production multipliers or Leontief inverse matrix $\mathbf{L}$, where each element $l_{i j}^{r s}$ indicates the increase in the production of sector $\mathrm{i}$ in country $r$ due to a unitary increase of demand of sector $\mathrm{j}$ in country s. $\mathbf{f}^{\text {st }}$ is the column vector with the final demand, with elements $f_{j}^{s t}$ indicating the final demand in country $\mathrm{t}$ for products of sector $\mathrm{j}$ produced by country s. This model is called demand-driven 
because for any new exogenous final demand $\mathbf{F}^{\prime}$, the total output $\mathbf{X}^{\prime}$ can be estimated as $\mathbf{x}^{\prime}=\mathbf{L F}^{\prime}$.

Value-added reflects the contribution of an industry to an economy (Miller \& Blair, 2009). Using value-added coefficients it is possible to differentiate the contribution of each country to the value-added embodied in a certain new expenditure (Dietzenbacher, Guilhoto, \& Imori, 2013). To calculate value-added coefficients the row vector of value-added in country $r \mathbf{w}^{\mathrm{r}}$, with elements $w_{i}^{r}$ indicating the value-added created in each sector $i$ of that country, is used. With this information and the inverse of the diagonal matrix of the gross outputs, value-added coefficients are obtained as $\mathbf{v}^{r}=\left(\hat{\mathbf{x}}^{r}\right)^{-1} \mathbf{w}^{r}$. The vector of value-added effects is calculated as $\mathbf{w}=\hat{\mathbf{v}} \mathbf{x}^{\prime}=\hat{\mathbf{v}} \mathbf{L} \mathbf{F}^{\prime}$. Thus, the value-added created in the country $\mathrm{r}$ as a consequence of a demand shock in country $\mathrm{t}$ is $\mathrm{W}^{r t}=\sum_{s} \mathbf{v}^{r} \mathbf{L}^{r s} \mathbf{f}^{\prime s t}$ 
Table 1. Types of adaptation projects and sources of information

\begin{tabular}{|c|c|c|c|}
\hline & Climate action & Type of intervention & NAPA Project \\
\hline \multirow{23}{*}{ 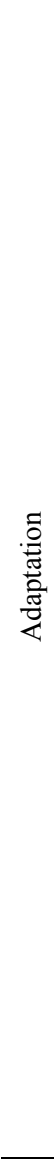 } & \multirow{3}{*}{$\begin{array}{c}\text { Coastal } \\
\text { protection }\end{array}$} & Beach nourishment & GAMBIA \#9 \\
\hline & & Coastal protection structures & CAPE VERDE \#3 \\
\hline & & Rehabilitation of coastal areas & SIERRE LEONE \#18 \\
\hline & \multirow{5}{*}{$\begin{array}{c}\text { Disaster risk } \\
\text { reduction }\end{array}$} & Early warning or emergency response systems & GAMBIA \#1 \\
\hline & & Construction or improvement of drainage systems & BHUTAN \#5 \\
\hline & & Flood protection & BHUTAN \#7 \\
\hline & & Hazard mapping and monitoring technologies & BHUTAN \#9 \\
\hline & & Improved climate services & SIERRE LEONE \#2 \\
\hline & \multirow{3}{*}{$\begin{array}{l}\text { Water supply } \\
\text { and } \\
\text { management }\end{array}$} & Rainwater harvesting and storage & SUDAN \#2 \\
\hline & & Rehabilitation of water distribution networks & SIERRE LEONE \#12 \\
\hline & & Desalinization, water recycling and water conservation & TUVALU \#3 \\
\hline & \multirow{7}{*}{$\begin{array}{c}\text { Human } \\
\text { settlements, } \\
\text { infrastructure } \\
\text { and spatial } \\
\text { planning }\end{array}$} & Energy security (hydropower) & TANZANIA \#5 \\
\hline & & Energy security (solar energy) & SIERRE LEONE \#8 \\
\hline & & Energy security (biomass) & GAMBIA \#6 \\
\hline & & Transport and road infrastructure adaptation & MALDIVES \#10 \\
\hline & & Protection of infrastructure & BHUTAN \#6 \\
\hline & & Zoning & SAMOA \#6 \\
\hline & & Improving the resilience of existing infrastructures/buildings & MALDIVES \#8 \\
\hline & \multirow{3}{*}{$\begin{array}{c}\text { Social } \\
\text { protection }\end{array}$} & Livelihood diversification & MALAWI \#1 \\
\hline & & Food storage and preservation facilities & LESOTHO \#8 \\
\hline & & Health, vaccination programmes & SIERRE LEONE \#23 \\
\hline & \multirow{2}{*}{$\begin{array}{c}\text { Waste and } \\
\text { wastewater }\end{array}$} & Sanitation & SIERRE LEONE \#22 \\
\hline & & Storm and wastewater & MALDIVES \#5 \\
\hline \multirow{12}{*}{ 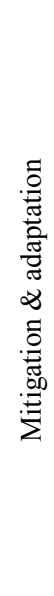 } & \multirow{5}{*}{$\begin{array}{c}\text { Forestry and } \\
\text { land use, } \\
\text { Terrestrial } \\
\text { Ecosystems }\end{array}$} & Afforestation and reforestation & ERITREA \#3 \\
\hline & & Ecological restoration and soil conservation & LESOTHO \#6 \\
\hline & & Protection of biodiversity & TUVALU \#5 \\
\hline & & Forest management, management of slopes and basins & BURUNDI \#3 \\
\hline & & Forest fires reduction & BHUTAN \#11 \\
\hline & \multirow{3}{*}{$\begin{array}{l}\text { Capacity } \\
\text { building }\end{array}$} & Awareness raising and integrating into education & BURUNDI \#11 \\
\hline & & Technical assistance & MALAWI \#5 \\
\hline & & Planning, policy development and implementation & SIERRE LEONE \#19 \\
\hline & \multirow{4}{*}{$\begin{array}{c}\text { Agriculture, } \\
\text { fishing and } \\
\text { livestock }\end{array}$} & Crop / animal diversification & SIERRE LEONE \#5 \\
\hline & & Crop, grazing land, livestock and fisheries enhanced management & ERITREA \#2 \\
\hline & & Research & MALDIVES \#9 \\
\hline & & Irrigation and drainage system & SIERRE LEONE \#7 \\
\hline
\end{tabular}

Source: Own work. 


\section{Table 2. Correspondence between NAPA categories and NACE codes}

\begin{tabular}{lc}
\hline \multicolumn{1}{c}{ NAPA expenditure categories } & NACE code \\
\hline Breeding animals, forage seeds, planting, crop management & 1 \\
Forest nurseries, re/afforestation, rehabilitation, beach stabilization, plantations & 2 \\
Materials, reporting, communication, awareness creation, training & 22 \\
Chemicals, drugs, raw materials & 24 \\
Materials for construction and rehabilitation & 26 \\
Tools & 28 \\
Machinery and installation & 29 \\
Office equipment & 30 \\
Transmission and distribution network & 31 \\
Laboratory/field/data processing eq., hydro/meteorology stations, telecom., remote sensing & 33 \\
Vehicles & 34 \\
Construction, rehabilitation, beach stabilisation, improve facilities/infrastructure & 45 \\
Logistics & 60 \\
Communication (campaign, networks, workshops) & 63 \\
Communication (telephone, internet and postal charges) & 64 \\
Micro-credit fund & 65 \\
Vehicle hiring charges & 71 \\
Research, experimentation, mapping & 73 \\
Technical support, design, management, planning, training & 74 \\
Institutionalisation of policies, support to collaborating agencies & 75 \\
Sanitary inspections, vector control measures, medical/veterinary services & 85 \\
Waste collection, sanitation & 90 \\
\hline
\end{tabular}


Table 3. Portion of impact captured by each country by climate action (\%)

$\begin{array}{llllllllllll}\text { Column number } & \text { (1) } & \text { (2) } & \text { (3) } & \text { (4) } & \text { (5) } & \text { (6) } & \text { (7) } & \text { (8) } & \text { (9) } & \text { (10) } & \text { (11) } \\ & \text { IND } & \text { BRA } & \text { CHN } & \text { IDN } & \text { MEX } & \text { AVG } & \text { EU } & & & & \\ \text { AVG }\end{array}$

\begin{tabular}{|c|c|c|c|c|c|c|c|c|c|c|c|}
\hline Coastal (A) & 86 & 88 & 80 & 83 & 82 & 84 & 4 & 3 & 2 & 1 & 2 \\
\hline$B$ insulation (EE) & 82 & 89 & 81 & 81 & 83 & 83 & 3 & 3 & 2 & 2 & 2 \\
\hline Forest (M\&A) & 87 & 87 & 80 & 79 & 78 & 82 & 4 & 4 & 2 & 1 & 3 \\
\hline Capacity (M\&A) & 86 & 87 & 78 & 78 & 76 & 81 & 5 & 4 & 2 & 1 & 3 \\
\hline T_RE (RE) & 89 & 84 & 83 & 77 & 68 & 80 & 4 & 4 & 2 & 1 & 3 \\
\hline Social P (A) & 84 & 85 & 73 & 75 & 74 & 79 & 6 & 4 & 2 & 1 & 3 \\
\hline Agriculture (M\&A) & 85 & 84 & 78 & 76 & 74 & 79 & 5 & 4 & 2 & 1 & 3 \\
\hline Waste (A) & 81 & 84 & 77 & 72 & 72 & 77 & 6 & 4 & 3 & 2 & 4 \\
\hline Geo_deep (RE) & 81 & 83 & 76 & 67 & 71 & 76 & 5 & 4 & 3 & 2 & 4 \\
\hline Biomass_big (RE) & 80 & 80 & 74 & 66 & 63 & 73 & 6 & 5 & 4 & 2 & 4 \\
\hline CSP (RE) & 83 & 77 & 72 & 70 & 60 & 72 & 6 & 5 & 5 & 2 & 4 \\
\hline Water (A) & 75 & 78 & 73 & 65 & 62 & 71 & 8 & 5 & 3 & 2 & 5 \\
\hline Infrastr (A) & 80 & 78 & 70 & 65 & 60 & 70 & 8 & 5 & 4 & 2 & 5 \\
\hline Wind_off(RE) & 81 & 77 & 71 & 65 & 57 & 70 & 7 & 6 & 4 & 3 & 5 \\
\hline T_infrastr (EE) & 79 & 74 & 70 & 70 & 53 & 69 & 8 & 6 & 4 & 2 & 5 \\
\hline Biogas (RE) & 80 & 76 & 71 & 58 & 57 & 68 & 7 & 6 & 4 & 2 & 5 \\
\hline Industry (EE) & 79 & 76 & 72 & 60 & 53 & 68 & 8 & 6 & 4 & 2 & 5 \\
\hline $\operatorname{DRR}(\mathrm{A})$ & 78 & 76 & 67 & 63 & 55 & 68 & 8 & 6 & 4 & 2 & 5 \\
\hline Biomass_small (RE) & 75 & 77 & 68 & 56 & 59 & 67 & 7 & 5 & 5 & 3 & 5 \\
\hline Solar_PV $(\mathrm{RE})$ & 73 & 75 & 65 & 67 & 55 & 67 & 6 & 5 & 5 & 2 & 5 \\
\hline Hydro (RE) & 80 & 71 & 68 & 54 & 44 & 63 & 9 & 7 & 5 & 2 & 6 \\
\hline Wind_on (RE) & 79 & 71 & 65 & 57 & 45 & 63 & 8 & 7 & 5 & 3 & 6 \\
\hline Geo_surface (RE) & 77 & 74 & 68 & 50 & 47 & 63 & 9 & 7 & 5 & 3 & 6 \\
\hline B_RE $(\mathrm{RE})$ & 79 & 69 & 68 & 57 & 42 & 63 & 9 & 7 & 6 & 2 & 6 \\
\hline Solar_thermal (RE) & 70 & 73 & 66 & 54 & 52 & 63 & 9 & 6 & 5 & 3 & 6 \\
\hline Ocean (RE) & 68 & 68 & 65 & 44 & 39 & 57 & 11 & 8 & 6 & 3 & 7 \\
\hline Average $\mathrm{M \& A}$ & 86 & 86 & 79 & 78 & 76 & 81 & 5 & 4 & 2 & 1 & 3 \\
\hline Average A & 80 & 81 & 73 & 70 & 66 & 75 & 7 & 5 & 3 & 2 & 4 \\
\hline Average EE & 82 & 81 & 77 & 72 & 64 & 73 & 6 & 5 & 3 & 2 & 4 \\
\hline Average RE & 77 & 75 & 69 & 59 & 53 & 68 & 8 & 6 & 5 & 2 & 5 \\
\hline
\end{tabular}

Source: Own work. Abbreviations: BRA (Brazil), CHN (China), EA (East Asia), EU (European Union), IDN (Indonesia), IND (India), MEX (Mexico), ODC (other developed countries), USA (United States of America), AVG (average), A (adaptation), Agriculture (agriculture, fishing and livestock), B insulation (building insulation), B_RE (renewable energy in buildings), Biogas (biogas power), Biomass_big (biomass energy large scale), Biomass_small (biomass energy small scale), Capacity (capacity building), Coastal (coastal protection), CSP (concentrated solar power), DRR (disaster risk reduction), Forest (forestry and land use/ terrestrial ecosystems), EE (energy efficiency), Geo_deep (deep geothermal energy), Geo_surface (surface geothermal power), Hydro (hydropower), Industry (energy efficiency in industry), Infrastr (human settlements, infrastructure and spatial planning), M\&A (mitigation and adaptation), ocean (ocean power), RE (renewable energy), Social P. (social protection), Solar PV (photovoltaics), Solar_thermal (solar thermal energy), T_infrastr (infrastructures for transport), T_RE (renewable energy in transport, biofuels), Waste (waste and wastewater), Water (water supply and management), Wind_off (offshore wind power), Wind_on (onshore wind power). 
Table 4. Impact captured by donor country, location and climate action (\%)

\begin{tabular}{|c|c|c|c|c|c|c|c|c|c|c|c|c|c|c|c|c|c|c|c|c|c|}
\hline & & & USA & & & & & EU & & & & & EA & & & & & ODC & & & \\
\hline & $\bar{z}$ & $\underset{\nabla}{\varpi}$ & $\widehat{B}$ & $\underset{z}{Z}$ & $\underset{x}{3}$ & $\bar{z}$ & $\underset{\nabla}{\varpi}$ & $\underset{Z}{Z}$ & $\underset{Z}{E}$ & $\underset{x}{3}$ & $\bar{z}$ & $\underset{\nabla}{\mathbb{D}}$ & $\mathbb{Z}$ & $\underset{Z}{Z}$ & $\underset{x}{3}$ & $\bar{z}$ & $\underset{\nabla}{\varpi}$ & 要 & $\underset{Z}{\Xi}$ & $\underset{x}{3}$ & $\mathrm{AVG}$ \\
\hline Ocean & 3 & 5 & 3 & 5 & 24 & 7 & 11 & 13 & 12 & 13 & 2 & 3 & 6 & 11 & 6 & 2 & 2 & 4 & 4 & 4 & 7 \\
\hline Geo_surface & 2 & 4 & 3 & 4 & 22 & 5 & 9 & 11 & 10 & 11 & 2 & 2 & 6 & 11 & 5 & 2 & 2 & 4 & 3 & 3 & 6 \\
\hline B_RE & 2 & 4 & 3 & 4 & 22 & 4 & 10 & 11 & 9 & 11 & 2 & 4 & 7 & 9 & 7 & 1 & 1 & 3 & 3 & 3 & 6 \\
\hline Hydro & 2 & 4 & 3 & 4 & 21 & 4 & 9 & 11 & 9 & 11 & 2 & 3 & 7 & 9 & 6 & 1 & 1 & 3 & 3 & 3 & 6 \\
\hline Wind_on & 2 & 5 & 4 & 4 & 19 & 4 & 9 & 11 & 7 & 10 & 2 & 3 & 7 & 9 & 6 & 2 & 2 & 4 & 3 & 4 & 6 \\
\hline Solar_thermal & 2 & 4 & 3 & 4 & 18 & 6 & 9 & 12 & 9 & 10 & 2 & 2 & 6 & 9 & 5 & 2 & 2 & 4 & 3 & 3 & 6 \\
\hline Industry & 2 & 3 & 3 & 3 & 19 & 4 & 9 & 9 & 8 & 9 & 2 & 2 & 5 & 8 & 5 & 2 & 1 & 3 & 3 & 3 & 5 \\
\hline $\mathrm{T}$ _infrastr & 2 & 4 & 3 & 2 & 21 & 4 & 10 & 11 & 5 & 8 & 2 & 3 & 5 & 6 & 7 & 2 & 1 & 3 & 2 & 3 & 5 \\
\hline DRR & 3 & 4 & 4 & 3 & 15 & 5 & 9 & 11 & 8 & 8 & 2 & 2 & 7 & 6 & 5 & 1 & 1 & 3 & 2 & 2 & 5 \\
\hline Biomass_small & 2 & 3 & 3 & 3 & 15 & 5 & 7 & 10 & 7 & 7 & 2 & 2 & 5 & 10 & 4 & 2 & 2 & 5 & 3 & 3 & 5 \\
\hline Biogas & 2 & 3 & 3 & 3 & 17 & 4 & 8 & 10 & 8 & 8 & 2 & 2 & 5 & 8 & 5 & 1 & 1 & 3 & 3 & 2 & 5 \\
\hline Infrastr & 2 & 3 & 3 & 3 & 15 & 4 & 8 & 10 & 8 & 8 & 1 & 2 & 6 & 6 & 4 & 2 & 1 & 3 & 2 & 2 & 5 \\
\hline Wind_off & 2 & 4 & 3 & 3 & 16 & 4 & 8 & 9 & 5 & 8 & 2 & 2 & 5 & 7 & 4 & 2 & 2 & 4 & 2 & 3 & 5 \\
\hline Solar_PV & 2 & 3 & 4 & 2 & 14 & 5 & 6 & 10 & 5 & 6 & 2 & 3 & 7 & 6 & 6 & 2 & 2 & 4 & 2 & 2 & 5 \\
\hline Water & 2 & 3 & 3 & 3 & 16 & 5 & 8 & 10 & 8 & 8 & 2 & 1 & 4 & 6 & 3 & 2 & 1 & 2 & 2 & 2 & 5 \\
\hline Biomass_big & 2 & 3 & 3 & 2 & 14 & 4 & 7 & 7 & 6 & 7 & 1 & 2 & 5 & 7 & 4 & 2 & 1 & 3 & 2 & 2 & 4 \\
\hline CSP & 2 & 3 & 3 & 2 & 14 & 3 & 7 & 8 & 4 & 6 & 1 & 3 & 6 & 6 & 6 & 1 & 1 & 3 & 2 & 2 & 4 \\
\hline Waste & 2 & 2 & 3 & 2 & 12 & 4 & 6 & 7 & 6 & 6 & 1 & 1 & 4 & 5 & 2 & 2 & 1 & 3 & 2 & 2 & 4 \\
\hline Geo_deep & 2 & 2 & 3 & 2 & 12 & 3 & 6 & 7 & 5 & 5 & 1 & 1 & 4 & 6 & 3 & 2 & 1 & 3 & 2 & 2 & 4 \\
\hline Social P & 2 & 2 & 4 & 2 & 11 & 3 & 6 & 9 & 5 & 6 & 1 & 1 & 4 & 4 & 2 & 1 & 1 & 2 & 2 & 1 & 3 \\
\hline Agriculture & 2 & 2 & 3 & 2 & 11 & 3 & 6 & 7 & 5 & 5 & 1 & 1 & 4 & 4 & 2 & 1 & 1 & 2 & 2 & 2 & 3 \\
\hline Capacity & 2 & 2 & 4 & 2 & 12 & 3 & 5 & 7 & 4 & 5 & 1 & 1 & 3 & 4 & 2 & 1 & 1 & 2 & 2 & 1 & 3 \\
\hline $\mathrm{T}_{-} \mathrm{RE}$ & 1 & 2 & 2 & 2 & 15 & 2 & 5 & 5 & 4 & 5 & 1 & 1 & 2 & 4 & 2 & 1 & 1 & 2 & 2 & 2 & 3 \\
\hline Forest & 2 & 2 & 3 & 2 & 10 & 2 & 4 & 6 & 4 & 4 & 1 & 1 & 3 & 4 & 2 & 1 & 1 & 2 & 2 & 1 & 3 \\
\hline Coastal & 1 & 2 & 2 & 1 & 7 & 3 & 5 & 5 & 3 & 3 & 1 & 1 & 4 & 2 & 2 & 1 & 1 & 2 & 1 & 1 & 2 \\
\hline B_insulation & 1 & 1 & 2 & 1 & 7 & 3 & 4 & 4 & 3 & 3 & 1 & 1 & 3 & 3 & 2 & 2 & 1 & 3 & 2 & 1 & 2 \\
\hline
\end{tabular}

Source: Own work. Abbreviations: BRA (Brazil), CHN (China), EA (East Asia), EU (European Union), IDN (Indonesia), IND (India), MEX (Mexico), ODC (other developed countries), USA (United States of America), AVG (average), Agriculture (agriculture, fishing and livestock), B_insulation (insulation of buildings), B_RE (renewable energy in buildings), Capacity B. (capacity building), Coastal (coastal protection), CSP (concentrated solar power), DRR (disaster risk reduction), Forestry (forestry and land use/ Terrestrial Ecosystems), Geo_deep (geothermal deep), Geo_surface (geothermal surface), Hydro (hydropower), Infrastr (human settlements), infrastructure and spatial planning), Ocean (ocean power), Social P. (social protection), Solar PV (photovoltaics), T_infrastr (transport infrastructure), T_RE (renewable energy in transport), Waste (waste and wastewater), Water (water supply and management), Wind_off (offshore wind), Wind_on (onshore wind). 


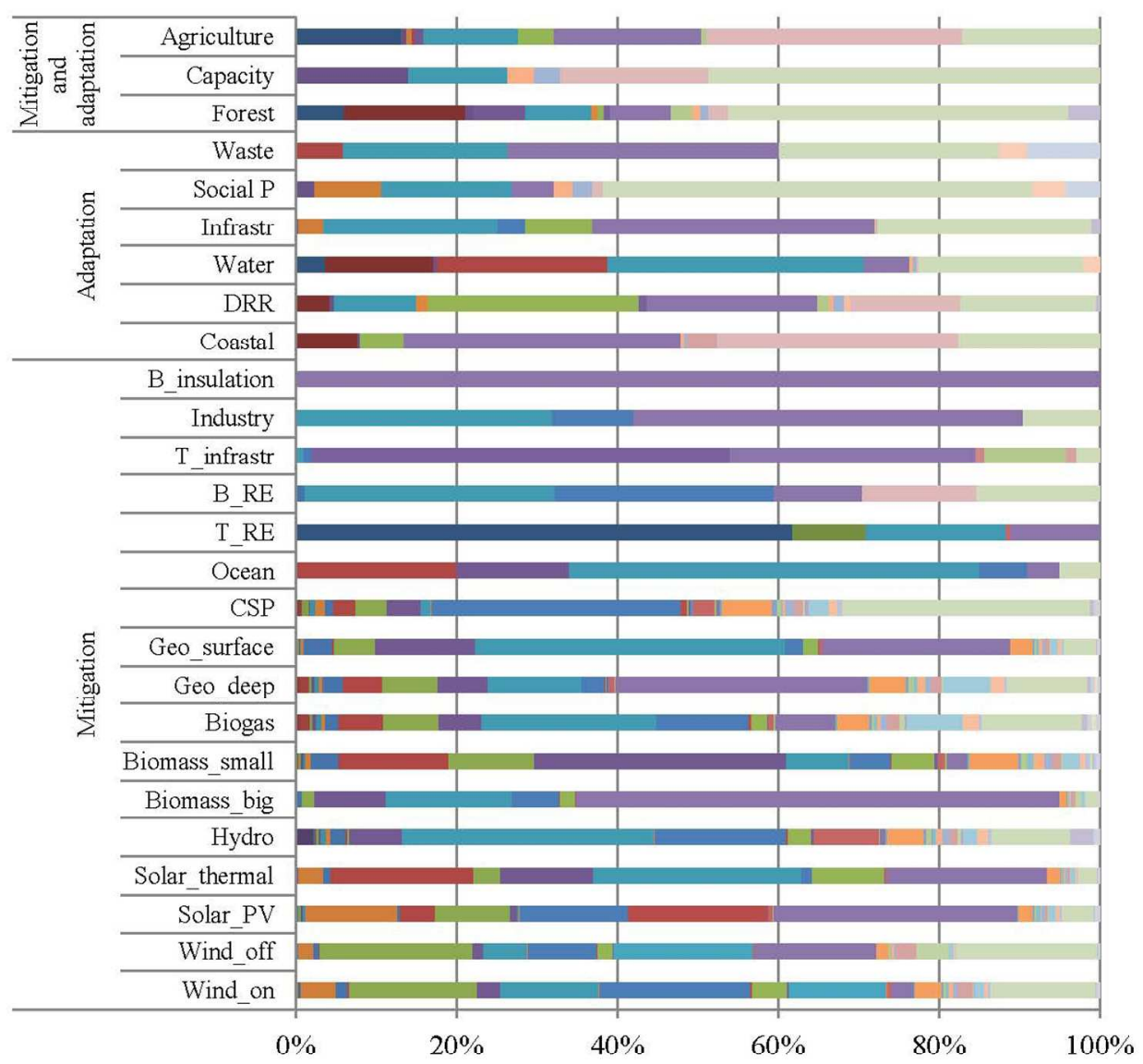

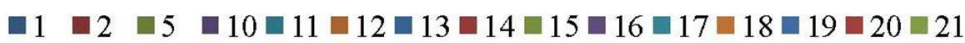

$\square 22 \square 23 \square 24=25 \square 26 \square 27 \square 28 \square 29 \square 30 \square 31=32 \square 33 \square 34 \square 35 \square 36$

$\square 37 \square 40 \square 41 \square 45 \square 50 \square 51 \square 52 \square 55 \square 60 \square 61 \square 62 \square 63 \square 64 \square 65 \square 66$

$\square 67 \square 70 \square 71 \square 72 \square 73 \llbracket 74 \square 75 \square 80 \square 85 \square 90 \square 91 \square 92 \square 93$

Figure 1. Cost structure per climate action.

Source: Lehr et al. (2012, 2008), Allan et al. (2008), Markaki et al.(2013), and UNFCCC (2014b). The description of commodity codes of the NACE classification is detailed in Table A.1. of the Appendix.

$170 \times 184 \mathrm{~mm}(200 \times 200$ DPI $)$ 


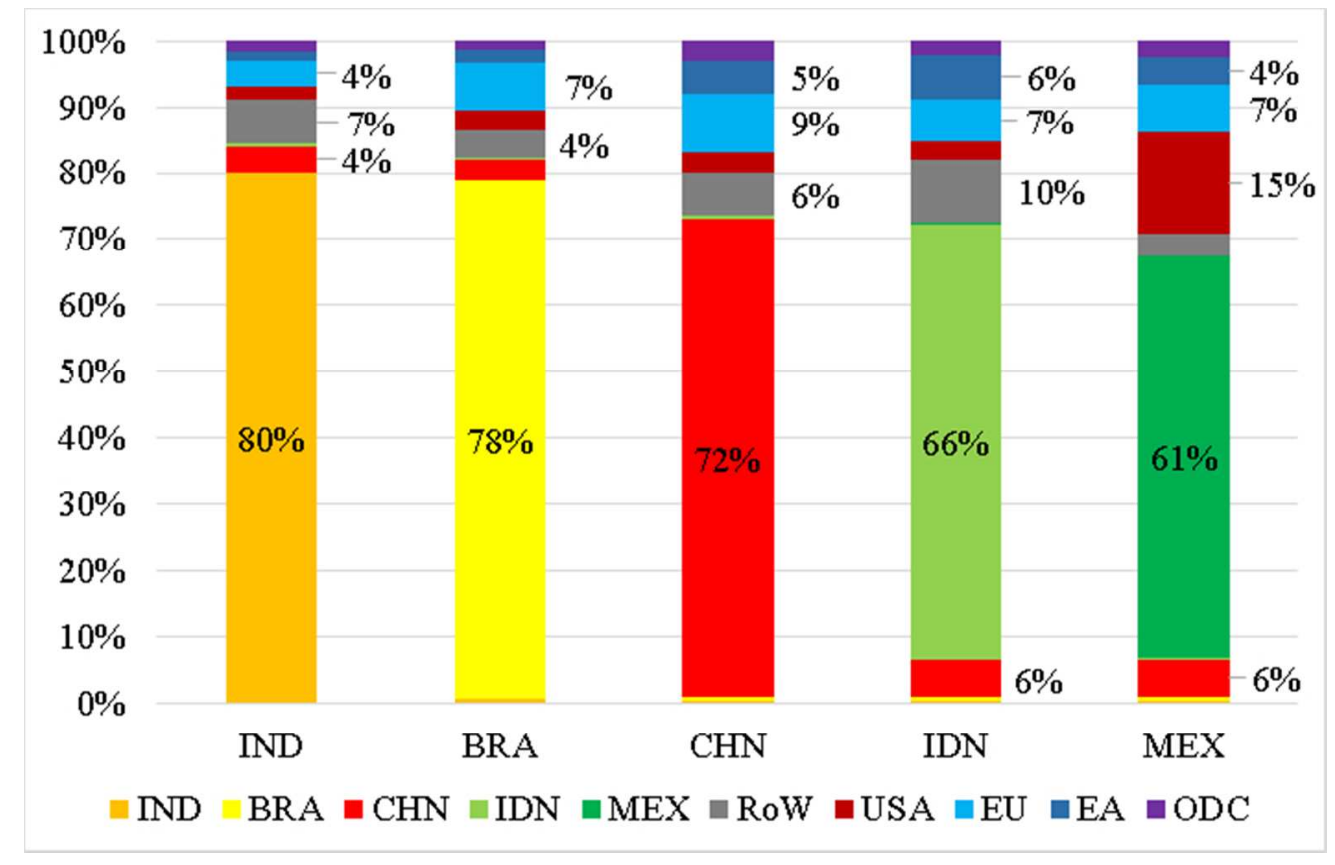

Figure 2. Geographic distribution of the impact by recipient country.

Source: Own work. Abbreviations: BRA (Brazil), CHN (China), EA (East Asia), EU (European Union), IDN (Indonesia), IND (India), MEX (Mexico), ODC (other developed countries), USA (United States of America). 
IND: 0.65

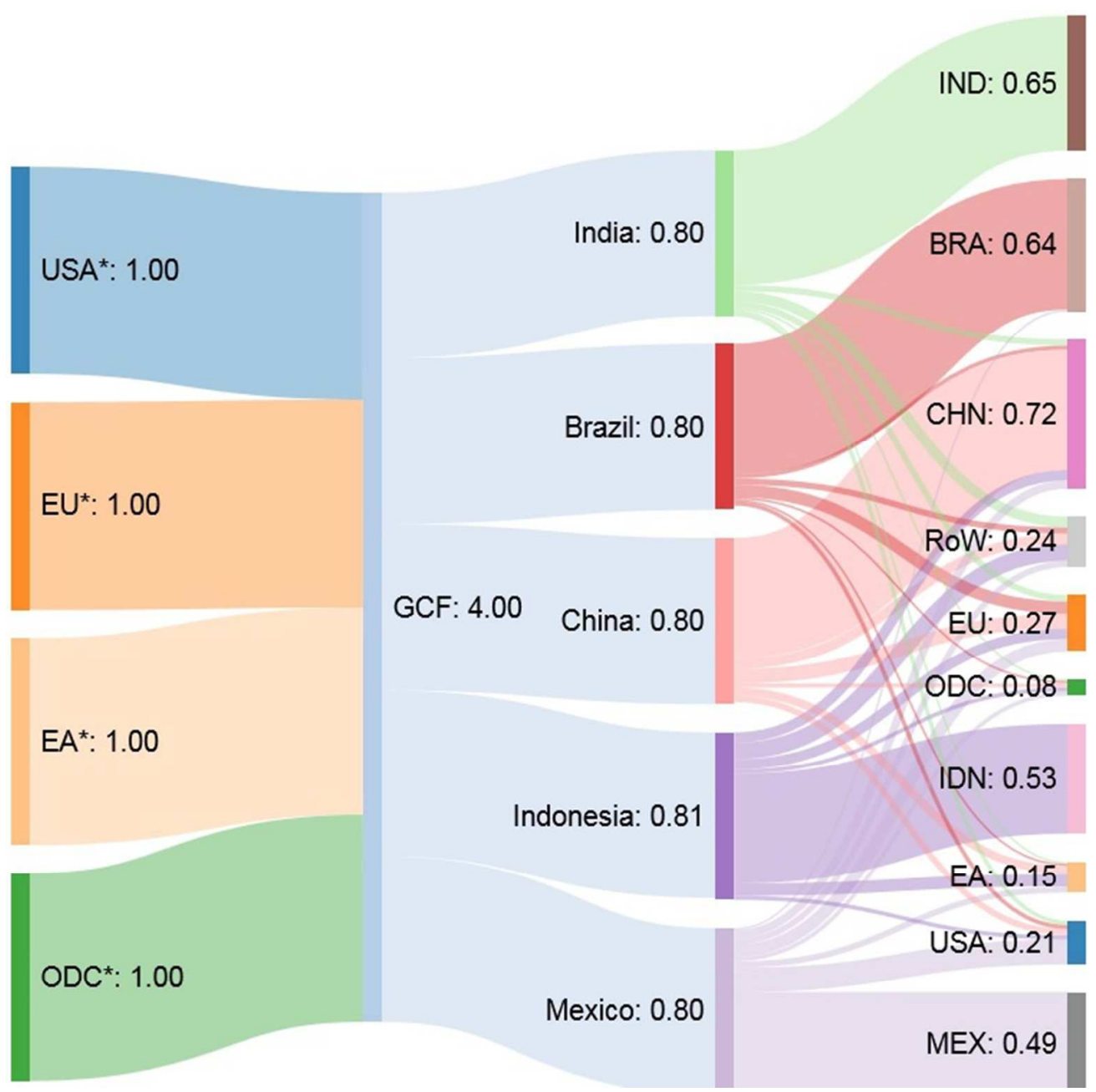

Figure 3. Example of financial flows from donors to recipients.

Source: Own work. Abbreviations: BRA (Brazil), CHN (China), EA (East Asia), EU (European Union), GCF (Green Climate Fund), IDN (Indonesia), IND (India),

MEX (Mexico), ODC (other developed countries), USA (United States of America), ROW (rest of the world).

$200 \times 197 \mathrm{~mm}(96 \times 96 \mathrm{DPI})$ 


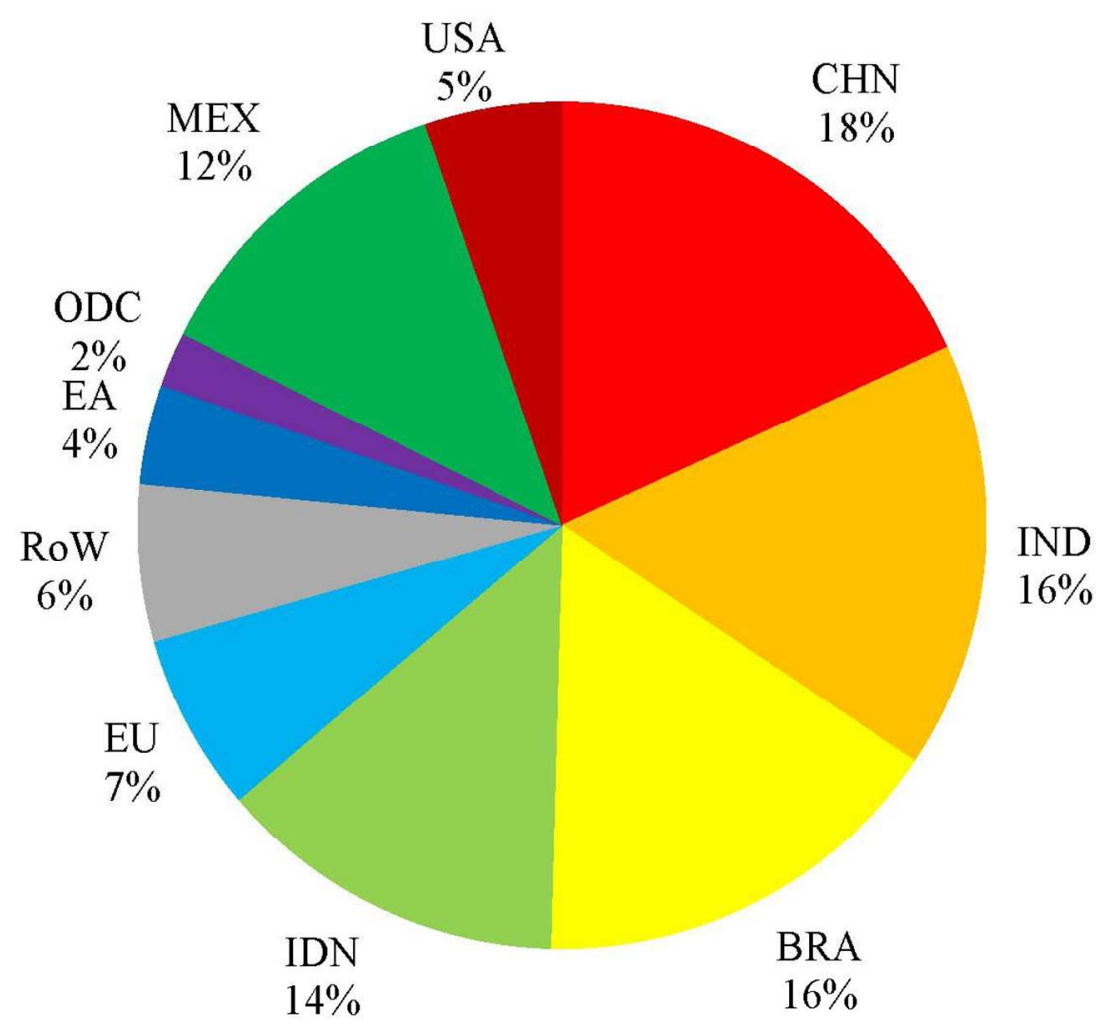

Figure 4. Distribution of the impact of a hypothetical climate fund.

Source: Own work. Abbreviations: BRA (Brazil), CHN (China), EA (East Asia), EU (European Union), GCF (Green Climate Fund), IDN (Indonesia), IND (India), MEX (Mexico), ODC (other developed countries), USA (United States of America), ROW (rest of the world).

$173 \times 147 \mathrm{~mm}(200 \times 200$ DPI $)$ 
Figure 5. Average spill-overs by type of climate action.

Source: Own work. Abbreviations: Agriculture (agriculture, fishing and livestock), B_insulation (building insulation), B_RE (renewable energy in buildings), Biogas (biogas power), Biomass_big (biomass energy large scale), Biomass_small (biomass energy small scale), Capacity (capacity building), Coastal (coastal protection), CSP (concentrated solar power), DRR (disaster risk reduction), Forest (forestry and land use/ terrestrial ecosystems), Geo_deep (deep geothermal energy), Geo_surface (surface geothermal power), Hydro (hydropower), Industry (energy efficiency in industry), Infrastr (human settlements, infrastructure and spatial planning), Ocean (ocean power), Social P. (social protection), Solar PV (photovoltaics),

Solar_thermal (solar thermal energy), T_infrastr (infrastructures for transport), T_RE (renewable energy in transport, biofuels), Waste (waste and wastewater), Water (water supply and management), Wind_off (offshore wind power), Wind_on (onshore wind power).

$170 \times 142 \mathrm{~mm}(200 \times 200$ DPI $)$ 